Covered in: ERIH PLUS, HeinOnline, CEEOL, Index Copernicus, CrossRef, CrossCheck, J-GATE, Google Scholar, Ideas RePeC, Econpapers, Socionet, KVK, WorldCat.

2020, Volume 8, Issue 1, pages: 47-52 | doi: 10.18662/lumenlaw/8.1/35

\section{Remedies and Sanctions for Non- compliance with Aspects Regarding the Authorization and Conduct of Special Methods of Supervision and Research}

\section{Denisa BARBU1}

${ }^{1} \mathrm{PhD}$. Lecturer, Valahia University of Târgovişte, Faculty of Law and Administrative Sciences, denisa.barbu77@yahoo.com
Abstract: Using special methods for surveillance and research is no longer a social novelty, considering that both the technology and the criminality have a long existence. It is also important to mention the fact that the dynamics of the regulation of this institutions had as a base two premises: first, as normal, the ratification of the Convention for the Protection of Human Rights and Fundamental Freedoms, and the second premise was the constant technological evolution. Regarding this last aspect, on a solid base it was considered that "the technical surveillance means will always be one step ahead of the legislation". Concerning the perspective of the analysis regarding the existence and the implementing necessity of the legislation, we can easily conclude that these methods, techniques presents, de plano an intrusive character.

Keywords: special methods, supervision, remedies, sanctions, techniques.

How to cite: Barbu, D. (2020). Remedies and Sanctions for Non-compliance with Aspects Regarding the Authorization and Conduct of Special Methods of Supervision and Research. Logos Universality Mentality Education Novelty: Law, 8(1), 47-52. doi:10.18662/lumenlaw/8.1/35 


\section{Introduction}

The distinction between the notion of sanction and the remedy is very important from the perspective of the present analysis, since the idea of sanction implies, in addition to bringing the entire criminal process in limite lex and the idea of punishment, of sanctioning the conduct of the individual, the latter representing the purpose of basic of the institution, while the notion of remedy pursues and at the same time places in the main plan the idea of safeguarding the whole procedure by trying to maintain within reasonable limits the trial and procedural activities.

Over time, several views have been expressed regarding the two remedies. We prefer to adopt the notion of remedy, in accordance with the European requirements in the field, in order to harmonize the entire lecture with the rights enshrined in the European Convention, but also with the idea of prevailing safeguarding procedures over the mere sanction of a conduct. In summary, although many points of view have been expressed in the sense of the existence of a remedy that enjoys autonomy in the matter of evidence, some authors (Mateut, 2019, p. 486; Udroiu, 2018, p. 974) have judged judiciously that such autonomy does not exist, the remedy of exclusion being subordinated to that of nullity, the effects of the first producing is through the second. In a much harsher sense, other authors have considered that the lack of autonomy of the remedy of exclusion is assimilated even to a cause of caducity, since being unable to produce legal effects mutu proprio would be essentially ineffective.

\section{Exclusion rule - Nullity or exclusion of illegally or unfairly administered evidence?}

From a legislative point of view, the remedy of exclusion is based both in the provisions of art. 102 NCCP as well as the provisions of art. 89 paragraph (2) NCCP, art. 190 paragraph (5) NCCP and art. 101 NCCP. The idea of subsuming the exclusion remedy of invalidity is enshrined in the provisions of art. 102 paragraph (3) which concerns the nullity of an act by which the administration of a sample was ordered or authorized. The other cases refer to express provisions for the remedy of exclusion in certain situations of serious infringement of the rights guaranteed by the European Convention on Human Rights (Council of Europe, 1950), which, although they concern hypotheses of virtual absolute nullity, will be removed by the effects of nullity without further proving (Udroiu, 2018, p. 980) the damage of these rights, based on its presumption to the legislator. The same reason 
will apply to the hypothesis of art. 102 paragraph (1), which deals with evidence obtained through torture and a fortiori, in agreement with other authors (Udroiu, 2018, p. 979), through inhuman or degrading treatment.

In the same note, art. 102 brings to light one of the rules that accompany the origin of the exclusion remedy, namely the remedy of excluding the derived evidence. Both the rule of exclusion and the rule of preclusion of derived evidence were taken by the Romanian legislator from the common law system. The latter is known and there are other names such as the rule of "remote effect" or "fruit of the poisonous tree" and which aim to apply the same effects with regard to the evidence obtained from those who ab initio were illegal. In this matter, the rule in question is treated relatively deficiently by the legislator who reminds of such an institution in par. (1) thesis II and paragraph (4) of art. 102 NCCP. According to art. 102 para. (4): „Evidence samples are excluded if they were obtained directly from illegally obtained evidence and could not be obtained otherwise". The idea of deficient regulation starts from the two conditions provided in paragraph (4), which places the remedy almost within the scope of the impossible, given that the last condition "could not be obtained otherwise" excessively restricts the fairness of the procedure. Finally, it is worth mentioning that the Constitutional Court of Romania has paid special attention to the institution of exclusion, and by Decision no. 22/2018, declared unconstitutional paragraph (3) of art. 102 stating with working authority that the effects of the exclusion should not concern exclusively the removal of the respective evidence only legally, but it is required sine qua non and a material removal thereof.

\section{The probative force of the means of evidence obtained from the special probative procedures.}

The notion of probative force is intimately linked to the cognitive process that involves the activity of forming a belief. The probationary force is a corollary of the activity of appreciation of evidence in the criminal trial. In the current regulation, it is enshrined, as we have heard from the beginning of the paper, the principle of the free appreciation of evidence in the sense that they do not have an established (art. 103 para. 1 NCCP) a priori probative force and there are no criteria that condition the probative force. The only exceptions to this rule are largely concerned with this issue as collaborators, investigators, or even third-party witnesses (by third-party witnesses we will refer to the persons who did not participate in the probationary procedures provided by art.148 and 150 NCCP and who can 
be heard as witnesses in the criminal trial), who benefit from procedural safeguards (Udroiu, 2018, p. 396) for threatened witnesses (art. 125 and art. 126 and the following. NCCP) will be heard in an exceptional manner, which could violate the right to defence, reason why the Romanian legislator understood to grant a probative conditional (Udroiu, 2018, p. 400) value by regulating the provisions of art. 103 paragraph (3) NCCP.

\section{Conclusions}

The existence of a regulation regarding the special methods of supervision and research is welcomed, given the speed they impose, for the optimal protection of the social values that can be harmed by committing crimes.

Starting from this idea, we can say that the special probationary procedures can help to identify and a fortiori prevention of the commission of both the crimes committed, or remained in tempted form, but also of the preparatory acts (for example identifying the intention to procure certain goods, or even making agreements between the participants, to materialize the criminal resolution). Preparatory acts are possible only in the case of intentional crimes, which presuppose the existence and an internal phase of the criminal process.

At the same time, it should be remembered that the purpose of the regulation is not exclusively the repression of cybercrime (in the regard that the material element cannot be accomplished in the absence of information media), but it also tends to the repression of crimes that can be committed by means of information technology (for example, the perpetration of a threatening crime through a public communications network), but we must not overlook the crimes that are not related to this "environment", but which can be discovered through such means.

Although modified in numerous lines, from the origin to the present day, the special probative procedures tend towards a "simplified" solution of the cases by obtaining some evidence (means of proof) with greater ease than the common law. The support is reinforced by the same idea that generated the proposals of law ferenda in the regard of the criticisms on the taking of the criteria developed in the common law and of the European Court of Human Rights, criteria that are, in our opinion, ineffective in the absence of legislative explanations, or granting clear criteria of appreciation within the meaning of the provisions of art. 318 NCCP.

It is also worth noting that of the four criteria only the one provided by the provisions of art. 139 paragraph (2) imposes an assessment in abstracto, 
the other three, respectively the proportionality of subsidiarity and necessity, implies a subjective assessment (in concrete), a situation which is deficient from our point of view, because by such mechanisms the arbitrariness can be created in the case of a motivation (regarding the proposals for authorization and confirmation of the probationary processes) which was based on means of evidence on which there is the possibility of not being known by the "accused" person and his/her defender, or means that can be excessively appreciated (for various reasons, for example the lack of sound evidence), which, in essence, should be imposed on the judge, who, although he has the sole discretion, cannot do it purely objective, motivated by the lack of objective criteria that meet the criteria that are required to be met. The problem does not just stop here, knowing that there is no appeal against the conclusion and the authorization order. In resolving this situation, the legislature has granted certain guarantees, essentially lacking in efficiency, such as the control in the preliminary chamber phase, according to the provisions of art. $342 \mathrm{NCCP}$, as a result of the exceptions raised ex officio or on the initiative of the parties or of the injured person, control which is "limited" only to the aspects of legality that the provisions mentioned recall. Regarding the faculty granted to the injured person to raise exceptions and to formulate requests in this matter, we express a slight doubt regarding the „interest" that this has to show, as it is very unlikely that the main procedural subject will formulate, for example, exceptions of illegality in this procedural phase in which the probatory was interpreted in favour, for the purpose of sending the defendant to trial. Thus restricting (we mention that the solution is not the same in the matter of the procedures provided by the provisions of art. 318 and 340 et seq. in which the judge will be able to check the merits) the possibility of the judge to verify only the legality, the possibility of exercising an effective control over the probationary process as a whole, from the moment of authorization until this procedural phase, the criteria of proportionality, subsidiarity and necessity are in principle impossible to be subject to such verification, as they are based only on solid aspects. We consider that in the resolution it will be possible to resort either to the motivation of the legality exception by reference to all the criteria that must be met for authorization, and in this motivation to use the proper grounds of argument in the sense of proving the non-fulfilment of the subjective criteria, or by a way much more difficult, namely that of regulating the law ferenda an appeal with elements of specificity similar to the procedures in the matter of waiving the criminal prosecution, the complaint against the classification solution, or in the field of insurance measures to be able to confer with the persons who appear before the judges and who have 
been subjected to such interference to benefit from concrete guarantees, applicable to ensure the full and complete observance of the guaranteed rights and freedoms, and not from virtual and de facto optional guarantees, because the execution of justice should be based on so much observance of the principles and activities imposed to find the truth, but in order to have a clear, purely objective truth, the justice system and implicitly the state will have to take care so much about the possibility of benefiting from certain guarantees (if given, the litigant could be in such a situation), as well as their effective and efficient granting in order to strengthen the confidence in the justice and avoid any regrettable situations of wrong appraisals, or lack of transparency.

We need to show that the procedural rule should set a balance point, it must object, transpose in a precise way the different situations that may arise in practice so that the entire criminal procedural activity has a stable basis.

Finally, we must not overlook the fact that we are in the process of reforming the criminal procedural framework, a reform which we tend to believe that will cover all the current deficiencies and which guarantee the idea of legislative stability by implementing an optimal legislative framework, by which to solve both the possible trial and procedural pathologies in general, as well as those of the special methods of supervision and research, in particular.

\section{References}

Constitutional Court of Romania. (2018). Decizia nr. 22/2018 referitoare la excepția de neconstituționalitate a dispozițiilor art. 102 alin. (3), art. 345 alin. (3) şi art. 346 alin. (4) din Codul de procedură penală [Decision no. $22 / 2018$ regarding the exception of unconstitutionality of the provisions of art. 102 para. (3), art. 345 para. (3) and art. 346 para. (4) of the Code of Criminal Procedure]. Monitorul Oficial al României, 177, 2018, February 26.

Council of Europe. (1950). European Convention on Human Rights. https:// www.echr.coe.int/documents/convention_eng.pdf

Mateuţ, G. (2019). Procedură penală. Partea generală [Criminal proceedings. The general part]. Universul Juridic.

Parliament of Romania. (2010). Lege nr.135 din 1 iulie 2010 privind Codul de procedură penală [Law no. 135 of July 1, 2010 on the Code of Criminal Procedure]. Monitorul Oficial al României, 486, 2010, July 15.

Udroiu, M. (2018). Procedură penală. Partea generală [Criminal proceedings. The general part] (4th ed.). C.H. Beck. 